\title{
Social gender in the pictures drawn by students about physical education class
}

\author{
Cenk Temel* and Mehmet Güllü \\ Inonu University, Turkey. \\ Received 09 December, 2015; Accepted 14 March, 2016
}

\begin{abstract}
The current study aimed to analyze the social gender perception in physical education classes in Turkey through the pictures drawn by students about the physical education class. The document analysis technique, which is a qualitative research method, was used in the study. In the light of this aim, the pictures drawn by a total of 394 students (190 females and 204 males) aged 11 years, who were enrolled in 12 schools in five different cities in Turkey were analyzed upon the permission obtained from the Ministry of National Education. The analysis included four themes and the themes were analyzed along with the results. It was concluded that although physical education classes are taught to mixed gender groups in Turkey, physical education class activities had an effect on female students shaping the formation of social gender, while they formed extremely sharp gender roles for male students.
\end{abstract}

Key words: Social gender, physical education, student.

\section{INTRODUCTION}

The concept of social gender is related to the references used in describing the relationships between genders. It also indicates how social relationships between the genders occur and how appropriate roles are created in the form of "cultural constructions" (Scott, 2007). The roles of male and female members in many societies differ in certain topics such as accessing resources, making decisions and participation (Desprez-Bouanchaud et al., 1987). In this respect, it is impossible to interpret the concept of social gender by separating the political and cultural intersection points within which it is produced and continued (Butler, 1999). This is because no one is born with social gender; everyone attains the roles of social gender (Beauvoir, 1993).
The concept of social gender provides a method to understand the complex links between various types of human interaction (Scott, 2007). This method enables the lifestyle of a community, as well as the cultural and moral norms to be evaluated in terms of relations of production. This evaluation indicated certain differences such as the participation of different genders in professional life, the distribution of these groups in society, their workloads, individual contributions, and social roles.

One of the social fields that could be interpreted through the concept of social gender is the field of sports. Research on social gender in the field of sports had been frequently analyzed, particularly in the 1980s within the scope of international sports sciences. Research on

*Corresponding author. E-mail:cenktemel@hotmail.com.

Authors agree that this article remain permanently open access under the terms of the Creative Commons Attribution License 4.0 International License 
sports sciences about social gender, sports, and physical education has a history of approximately 15 years in Turkey (Koca, 2007). Particularly, in the field of physical education, there were intense discussions about how to prevent the obstacles hindering individual participation between the 1990s and early 2000s (Theodoulides, 2003).

Anderson (2008) reported that gender discrimination had deep roots within athletic organizations and practices and sports culture. Connell (1987) stated that athletic environments enabled social gender inequality and formed a new cultural practice where social gender perception was reproduced. The following quotation of Lomansey (2007) illustrated this perspective:

"The visibility of women athletes, trainers, and promoters in today's sports world is a far cry from their status just slightly more than a century ago. When the first Olympic Games of the modern era took place in 1896, the idea of women taking part was thought to be "unfeminine". Since then, it is easy to see the progress that has since been made in many parts of the world. By 1900, societal views had modernized enough to allow 11 women to stand beside the 1319 men at the opening ceremony at the Paris Olympics, although their participation was restricted to sports regarded as "suitable" for women -tennis and golf."

Since the modern Olympics started, there have been improvements in social gender equality, although they are not satisfactory. On the other hand, advanced athletic organizations such as the Olympic Games have given ideas about social gender; however, the main point lies in how the fundamentals of values about social gender are created or established. Hence, it is believed that the way physical education classes are taught have an essential role in students in terms of developing attitudes towards physical education and sports, which they would display in their future lives. Therefore, many national or international institutions have taken advisory decisions that physical education curricula and content should be implemented so as to serve social gender equality. Athletic activities have been included in the rights for education within the studies performed by UNICEF (2007) in the implementation of children's rights for education and rights in education. Additionally, it has been emphasized that all children, male or female, should have improved access to the playgrounds and sports facilities in and around schools (UNICEF, 2007). Another UNICEF report mentioned that social gender patterns should be eliminated from all teaching and learning materials ${ }^{1}$ (A Booklet of Approach Based on Human Rights in Education for All, p.33-68). The "White Book of Sports," issued by the European Commission (2007), aimed at improved access to sports for girls and women. As repeated in the MINEPS 2013 Berlin Declaration, the participation of girls was reported to be improved through sports $^{2}$. Analyzing local approaches, it was observed that the physical education strategy of Bulgaria and England aimed to improve the participation of all human beings, regardless of their social, financial, health and gender status (Eurdice, 2012). The elementary physical education curriculum guide in Turkey indicates that all students, either male or female, should be taught together in physical education classes (Turkish Elementary Physical Education Curriculum, 2007).

However, despite all these positive efforts, there are still negative examples about social gender in the physical education classes taught in schools. Kirk (2012) indicated that there were challenges to the participation of female students in physical education and athletic activities, in spite of research results stating the benefits of participating in physical education and athletic activities. On the other hand, Hardman (2008) identified that physical education classes around the world have been struggling with the obstacles that hinder the full participation of disabled children, as well as social gender equality. In his findings, Eurydice (2010) indicated that female students scored better in all classes other than compulsory physical education and health classes; however, male students were better only in physical education classes. Despite the fact that the aim of eliminating gender inequality in elementary schools has been achieved in Turkey, gender discrimination still remains as an issue that requires attention. ${ }^{3}$

This study, as a result of the earlier mentioned positive or negative implementations at the national or international level, aimed to analyze the social gender perception about physical education classes taught in Turkey, with the aid of the pictures drawn by students about physical education classes.

\section{MATERIALS AND METHODS}

Studies involving pictures drawn by students have been widely used in various fields of science, such as psychology and medicine. Hence, children are able to express their emotions, thoughts, and observations about their environment through pictures (Yavuzer, 2009). In particular, performing research on pictures drawn by students has become more popular in all fields, following study by Chambers (1983) called the "Draw-A-Scientist Test". In the field of physical education, although they are quite limited in number, there have been studies performed by having children draw pictures (Kuhn, 2003; MacPhail and Kinchin, 2004; Mowling et al., 2006; Temel and Güllü, 2014). This study made use of the document analysis technique, which is a qualitative research method. With this aim, having obtained the required permission from the Turkish Ministry of National Education (no. 930210, dated 4.03.2014), pictures about physical education, which were drawn by a total of 394 11-year-old students (190 female and 204 male), enrolled at 12 schools in five different cities (İstanbul, Muğla, Ankara, Malatya, Trabzon) of Turkey, were analyzed separately.

\section{Data analysis}

Pictures drawn by the students were analyzed through the content analysis technique. Within the analysis, first all pictures were examined individually and the pictures with inappropriate content 
Table 1. Gender Status of Human Figures in Pictures Drawn by Female Students.

\begin{tabular}{lcc}
\hline Gender & Frequency (f) & Percentage (\%) \\
\hline Only girl(s) & 84 & 44.21 \\
Boy and girl & 54 & 28.43 \\
Only girl(s) & 52 & 27.36 \\
Total & 190 & 100 \\
\hline
\end{tabular}

were eliminated. Next, four major themes were identified within the analysis. They included:

Theme 1: What is the distribution of genders in the pictures drawn by male and female students?

Theme 2: What is the total number of people in the pictures of female and male students?

Theme 3: What sportswear are the people wearing in the pictures drawn by male and female students?

Theme 4: What are the types of sports played by the people in the pictures drawn by male and female students?

First step: The themes that were identified in the pictures were analyzed separately by the researchers and the frequencies of the themes were determined.

Second step: Data obtained by the researchers separately were compared, and then were reanalyzed together. After the two steps, it was found that while some of the pictures involved a single theme, many others had drawings of more than one theme.

Third step: In order to increase the validity and reliability at the final decision phase of the analysis performed by the researchers, an independent visual arts expert was requested to provide his opinion (Roberts and Priest, 2006). The final decision for each data set was provided upon the consensus reached by the researchers and the visual arts expert. Pictures on which a consensus was not reached were eliminated from the analysis. As a result of all the analyses, the frequencies and percentages of the themes in 394 agreed-upon pictures were determined and presented in tables.

\section{FINDINGS}

In this section, data regarding the pictures drawn by female and male students are presented separately.

\section{Findings about the pictures drawn by female students}

It was determined that $44,21 \%$ of female students ( 84 students) out of survey group (190 students) drew mostly female figures, while almost identical rates were observed for a combination of female and male figures and in a very close rate for only male figures (Table 1 ). The rate of female figures is $64,34 \%$ (583 figures) of total (839 figures) figures in pictures drawn by female students (Table 2).

\section{Clothing in pictures drawn by female students}

The clothing is observed to be tracksuit for females $(f=247, \% 45,91)$ and males $(f=190, \% 63,75)$ in pictures
Tablo 2. The total number of human figures and their gender in pictures drawn by female students.

\begin{tabular}{lcc}
\hline Gender & Frequency (f) & Percentage (\%) \\
\hline Female & 538 & 64.34 \\
Male & 298 & 35.66 \\
Total & 839 & 100 \\
\hline
\end{tabular}

Table 3. Clothing of female figures in pictures drawn by female students.

\begin{tabular}{lcc}
\hline Variable & Frequency (f) & Percentage (\%) \\
\hline Tracksuit & 247 & 45.91 \\
School Uniform & 141 & 26.21 \\
None & 79 & 14.68 \\
Jerseys & 53 & 9.86 \\
Shorts & 18 & 3.34 \\
Total & 538 & 100 \\
\hline
\end{tabular}

Table 4. Clothing of male figures in pictures drawn by female students.

\begin{tabular}{lcc}
\hline Variable & Frequency (f) & Percentage (\%) \\
\hline Tracksuit & 190 & 63.75 \\
None & 53 & 17.80 \\
Jerseys & 35 & 11.74 \\
School Uniform & 20 & 6.71 \\
Total & 298 & 100 \\
\hline
\end{tabular}

drawn by female students (Tables 3 and 4 ).

\section{Sports branches in the pictures drawn by female students}

The sports branches which were mostly pictured in drawings made by female students were volleyball $(\mathrm{f}=84$, $\% 47,72)$ for girls and soccer $(f=26, \% 30,95)$ for boys (Tables 5 and 6).

\section{Findings about the pictures drawn by male students}

It was observed that the majority of figures were only male figure(s) with a rate of $82,35 \%$ (168 individuals) in the pictures drawn by male students (Table 7 ). The rate of male figures is $88,05 \%$ (951 figures) out of a total of 1080 figures (Table 8 ).

\section{Clothing in pictures drawn by male students}

The clothing is observed to be jerseys for male figures 
Table 5. Sports branches of female figures in pictures drawn by female students.

\begin{tabular}{lcc}
\hline Variable & Frequency (f) & Percentage (\%) \\
\hline Volleyball $^{*}$ & 84 & 47.72 \\
Basketball $^{*}$ & 48 & 27.37 \\
Soccer & 6 & 3.4 \\
Rope skipping & 16 & 9.0 \\
Athletics & 2 & 1.13 \\
Table tennis & 12 & 6.91 \\
Tennis & 1 & 0.5 \\
Sitting aside & 7 & 3.97 \\
Total & 176 & 100 \\
\hline
\end{tabular}

Table 6. Sports branches of male figures in pictures drawn by female students.

\begin{tabular}{lcc}
\hline Variable & Frequency (f) & Percentage (\%) \\
\hline Soccer & 26 & 30.95 \\
Basketball $^{*}$ & 22 & 26.29 \\
Volleyball $^{*}$ & 12 & 14.20 \\
Handball $_{\text {Rope skipping }}$ & 2 & 2.38 \\
Table tennis & 2 & 2.38 \\
Physical activity & 4 & 4.76 \\
Total & 16 & 19.04 \\
\hline
\end{tabular}

Note: *It was observed that boys and girls were playing volleyball and basketball together in some pictures.

Table 7. Gender status of human figures in pictures drawn by male students.

\begin{tabular}{lcc}
\hline Gender & Frequency (f) & Percentage (\%) \\
\hline Only boy(s) & 168 & 82.35 \\
Only girl(s) & 24 & 11.77 \\
Boy and girl & 12 & 5.88 \\
Total & 204 & 100 \\
\hline
\end{tabular}

$(\mathrm{f}=247, \% 45,91)$ and tracksuit for female figures $(\mathrm{f}=190$, $\% 63,75)$ predominantly in pictures drawn by male students (Tables 9 and 10).

\section{Sports branches in the pictures drawn by male students}

The number one sports branches which were mostly pictured in drawings made by male students were soccer $(\mathrm{f}=126, \% 49,42)$ for boys and volleyball $(\mathrm{f}=16, \% 50,00)$ for girls (Tables 11 and 12; Figures 1 and 2).
Table 8. The Total Number of Human Figures and Their Gender in Pictures Drawn by Male Students.

\begin{tabular}{lcc}
\hline Gender & Frequency (f) & Percentage (\%) \\
\hline Female & 951 & 88.05 \\
Male & 129 & 11.95 \\
Total & 1080 & 100 \\
\hline
\end{tabular}

Table 9. Clothing of male figures in pictures drawn by male students.

\begin{tabular}{lcc}
\hline Variable & Frequency (f) & Percentage (\%) \\
\hline Jerseys & 384 & 40.38 \\
Tracksuit & 348 & 36.59 \\
None & 201 & 21.14 \\
School uniform & 18 & 1.89 \\
Total & 951 & 100 \\
\hline
\end{tabular}

Table 10. Clothing of female figures in pictures drawn by male students.

\begin{tabular}{lcc}
\hline Variable & Frequency (f) & Percentage (\%) \\
\hline Tracksuit & 68 & 52.71 \\
School uniform & 33 & 25.59 \\
None & 25 & 19.37 \\
Jerseys & 3 & 2.33 \\
Total & 129 & 100 \\
\hline
\end{tabular}

\section{RESULTS AND DISCUSSION}

According to the findings of the study, within the theme of gender status of people in a physical education lesson, there was not a major difference in the only female, only male, female-male, and male-male subthemes; however, male students were observed to mainly draw male students with male students (Table 7). It is believed that this was due to the fact that male figures were pictured playing football (Table 11) and football was generally perceived as a male sport in Turkey. In the total number of human figures and their gender themes, female students were observed to have depicted the two genders in equal numbers; however, male students drew fewer female figures and more male figures. In the details of the pictures drawn by the male students, male figures were pictured in competition with each other and there were images related to competition, power, stability, and similar concepts. Both findings were quite significant. The gender inequality experienced in certain sports branches (Dashper, 2012) could have occurred due to the activities in the physical education classes.

Hargreaves (1994) indicated that school has a potential 
Table 12. Sports branches of female figures in pictures drawn by male students.

\begin{tabular}{lcc}
\hline Variable & Frequency (f) & Percentage (\%) \\
\hline Volleyball $^{*}$ & 16 & 50.00 \\
Basketball $^{*}$ & 10 & 31.20 \\
Soccer & 3 & 9.40 \\
Sitting aside & 3 & 9.40 \\
Total & 32 & 100 \\
\hline
\end{tabular}

Note: *It was observed that boys and girls were playing volleyball, basketball and making physical activity together in some pictures with a lower rate than that of female pictures.

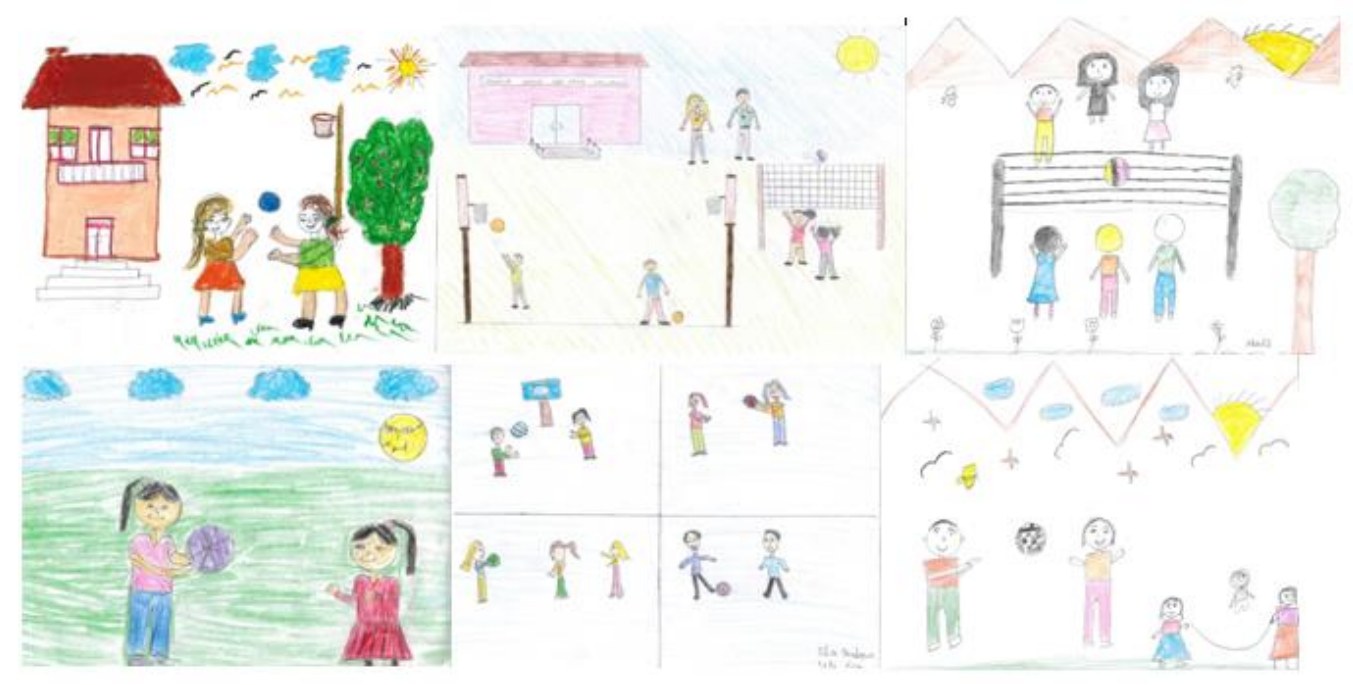

Figure 1. Sample pictures drawn by the female students.

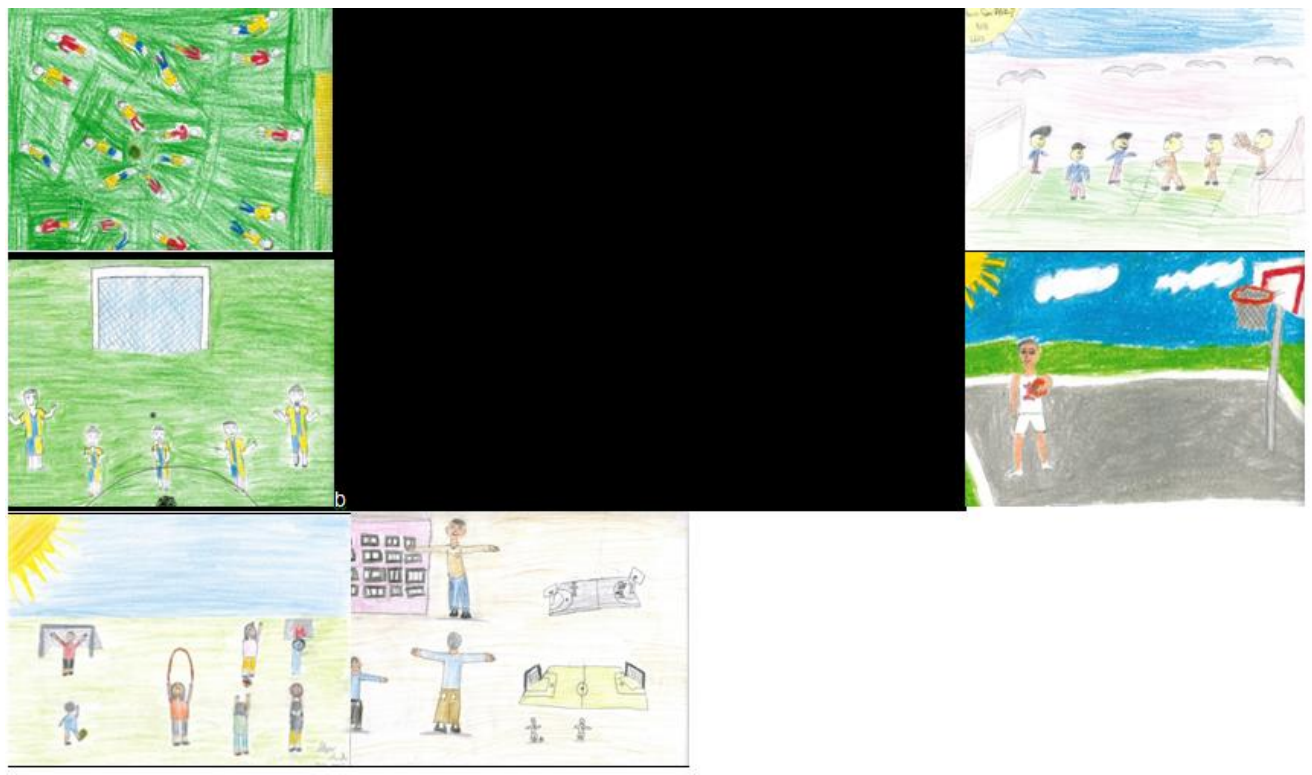

Figure 2. Sample pictures drawn by the male students. 
that could cunningly empower the gender perceptions through organization, administration, and teaching methods. On the other hand, physical education classes are the fields in which social gender differences are experienced in most schools (Flintoff, 1990; Hargreaves, 1994). In addition to the course content, this experience could be related to the social gender perceptions of the physical education teachers. Hence, physical education classes enable the presentation of gender roles through the content and student group activities (Lines and Stidder, 2003). Karaçam and Koca (2012) highlighted that the effects of social gender on the experiences of male and female students should be recognized by the teachers in order to ensure equal participation in the class.

In the student's clothes theme, it was found that female students drew both themselves and male students mainly with sportswear, while male students pictured themselves favorably in uniforms. Accordingly, it has been understood that female students did not perceive physical education class solely as winning, competing while male students related the class with such emotions as competition, beating, fighting and similar emotions. In the sports branches theme, in the pictures drawn by both female and male students, it was observed that male students were pictured playing football, while female students were drawn playing volleyball. This may have stemmed from the common perception that male students play football and female students play volleyball in the physical education classes in Turkey.

In a research conducted by Zaravigka and Pantazis (2012) in Greece, the sports of female and male students were identified to be different, both genders were observed to develop endurance and display skills through physical education classes, and physical education teachers were found not to provide equal opportunities for female students in fitness classes compared to male students. In order to decrease the number of such cases, Clarke and Nutt (1999) suggested that certain sports that could be played by both genders, such as handball and korfball, should be taught in physical education classes. Furthermore, instead of favoring a certain sports branch in physical education classes, playing cooperative games was reported to decrease gender differences (Lundvall and Meckbach, 2014; Ryan and Poirier, 2012).

As in many societies, school is an important factor for females and males in learning their social gender roles in the Turkish society (Kağıtçıbaşı, 1982). Markovic and Milanovic (2014) indicated that gender had a significant effect on the attitudes towards the physical education course, and that the attitudes of male students towards physical education courses were more positive than those of the female students. According to the findings obtained in the study, it could be said that the function of physical education classes as the fields where male students who demonstrated their masculinity. Therefore, through these attitudes, behaviors, and athletic performance, male students are believed to provide significant references to other social environments. Today, a transition is experienced in teaching physical education and sports from teacher-centered education towards student-centered education (Thorburn and Gray, 2010). However, student-centered education could be realized when students of different genders, beliefs, races, skills, and abilities participate in the lessons in an inclusive manner.

Examining the four themes obtained as a result of the study with their results, it could be reported that although physical education classes are taught in mixed gender classes in Turkey, they had an impact on female students in terms of developing social gender; however, they created quite a sharp gender roles for male students. Despite the fact that the physical education curriculum requires teaching physical education classes without differentiating between male and female students (Turkish Elementary Physical Education Curriculum, 2007), the applications in the classes were observed to be different. Therefore, it is suggested that physical education teachers are provided with pre-service and inservice training on social gender awareness.

\section{Conflict of Interests}

The authors have not declared any conflicts of interest.

\section{REFERENCES}

Anderson E (2008). 'I used to think women were weak': Orthodox masculinity, gender segregation and sport. Sociol. Forum 23(2):257280.

Beauvoir DS (1993). Kadın-İkinci Cins (Çeviren: Bertan Onaran). Payel Yayınevi, İstanbul.

Butler J (1999). Gender Trouble Feminism and the Subversion of Identity. Routledge Taylor \& Francis Group.

Chambers DW (1983). Stereotypic Images of the Scientist: The Draw a Scientist Test. Sci. Educ. 67 (2):255-265.

Clarke G, Nutt G (1999). "Physical Education", in D. Hill and M. Cole (eds), Promoting Equality in Secondary Schools, London: cassell. pp. 211-237.

Connell RW (1987). Gender and Power. Stanford University Press, California.

Dashper K (2012). "Together, yet still not equal? Sex integration in equestrian sport”. Asia-Paci. J. Health Sport Phys. Educ. 3(3):213225.

Declaration on Physical Education National Summit, (2005). http://www.publications.parliament.uk/pa/cm200708/cmselect/cmchils ch/memo/natcurric/ucm4002.htm (Viewed: 03.03.2015)

Desprez-Bouanchaud A, Doolaege J, Ruprecht L (1987). Guidelines on gender-neutral language. Paris: UNESCO.

Eurydıce [EU] (2010) Eğitim çıktılarında cinsiyet farklılıkları: Avrupa'da alınan tedbirler ve mevcut durum.http://eacea.ec.europa.eu/education/eurydice/documents/them atic_reports/120TR.pdf (Viewed: 03.03.2015).

Eurydice [EU] (2014). Council conclusions of 21 may 2014 on gender equality in sport http://mpes.government.bg/Documents/Documents/International/201 4/Council_Conclusions_Gender_Equality.pdf. (Viewed: 12.05. 2015).

Flintoff A (1990). Physical education, equal opportunities and the national curriculum: Crisis or challenge?. Phys. Educ. Rev. 13(2):85100.

Hardman K (2008). "Situation and Sustainability of Physical Education 
In Schools: A Global Perspective". Spor Bilimleri Dergisi Hacettepe J. Sport Sci. 19(1):1-22.

Hargreaves $J$ (1994). Sporting females: critical issues in the history and sociology of women's sports, Routledge, London.

UNESCO [UN] (2013). Declaration of Berlin. Available at: http://unesdoc.unesco.org/images/0022/002211/221114e.pdf

United Nations Development Programme [UNDP] (2013). About Turkey. http://www.tr.undp.org/content/turkey/tr/home/countryinfo/\#Güçlükler (Viewed: 24.09.2015)

United Nations Development Programme [UNDP] (2015). Gender Equality. http://www.undp.org/content/undp/en/home/sdgoverview/post-2015development-agenda/goal-5.html. (Viewed: 12.08.2015).

Unicef (2007). A human rights based approach to education for all. http://www.unicef.org/publications/files/A_Human_Rights_Based_App roach_to_Education_for_All.pdf. (Viewed: 17.9.2015).

Kağıtçıbaşı Ç (1982). Sex roles, family and community in Turkey, Indiana University Turkish Studies 3, Indiana.

Karaçam MŞ, Koca C (2012). "Preservice Physical Education Teachers' Awareness of Multiculturalism". Hacettepe J. Sport Sci. 23(3):89-103.

Koca C (2007) "Beden Eğitimi ve Spor Alanında Toplumsal Cinsiyet İlişkileri" Spor Bilimleri Dergisi Hacettepe J. Sport Sci. 17(2):81-99.

Kirk D (2012). Empowering Girls and Women through Physical Education and Sport - Advocacy Brief. Bangkok, UNESCO.

Kuhn P (2003). "Thematic Drawing and Focused, Episodic Interview Upon The Drawing-A Method In Order to Approach to The Children's Point of View on Movement, Play, and Sports at School". Q. Soc. Res. 4:1.

Lines G, Stidder G (2003). Equity and Inclusıon In Physical Education And Sport. Routledge Taylor and Francis Group Press, New York.

Lomansey K (2007) Gender Equality around the World. Articles from World of Work Magazine 1999-2006. International Labor Organization, Geneva.

Lundvall S, Meckbach J (2014). Mind the gap: physical education and health and the frame factor theory as a tool for analysing educational settings. Phys. Educ. Sport Pedagogy 13(4):345-364

MacPhail A, Kinchin G (2004)."The use of drawings as an evaluative tool: students' experiences of Sport Education. Phys. Educ. Sport Pedagogy 9(1):87-108.

Markovic, Z, Milanovic S (2014). The Attıtudes of Female Students Sportswomen and Non Sportswomen about Sport and Physical Education. Activities Phys. Educ. Sport 4(1):63-66.
Mowling CM, Brock SJ, Hastie PA (2006). "Fourth Grade Students' Drawing Interpretations of a Sport Education Soccer Unit". J. Teach. Phys. Educ. 25:9-35.

Roberts P, Priest H (2006). Reliability and validity in research. Nursing Standard 20:41-45.

Ryan T, Poirier Y (2012). Secondary Physical Education Avoidance and Gender: Problems and Antidotes. Int. J. Instruct. 5:2.

Scott WJ (2007). Toplumsal Cinsiyet: Faydalı Bir Tarihsel Analiz Kategorisi (Çeviren: Aykut Tunç Kılıç) Agora Kitaplığı, İstanbul.

Temel, C., Güllü, M. (2014). "Öğrencilerin Beden Eğitimi Dersine İlişkin Resimlerinde Toplumsal Cinsiyet". Uluslararası Toplumsal Cinsiyet Sempozyumu Bildiri Kitabı, Sayfa 4, Hacettepe Üniversitesi, Ankara.

Theodoulides A (2003). Curriculum Planning for Inclusion in Physical Education", in Equity and Inclusion in Physical Education and Sport.(Edited by Sid Hayes and Gary Stidder). Routledge Taylor\&Francis Group, London and New York.

Thorburn M, Gray S (2010). Physical Education: Picking Up The Baton. Dunedin Academic Press, Edinburgh.

Turkish Elementary Physical Education Curriculum, (2007). Milli Eğitim Bakanlığı Devlet Kitapları Müdürlüğü, Ankara.

Unicef (2007). Herkes İçin Eğitime İnsan Haklarını Temel Alan Bir Yaklaşım Kitapçığı. Birleşmiş Milletler Yayını, Ankara.

Yavuzer H (2009). Resimleriyle Çocuk. Ankara: Remzi Kitapevi.

Zaravigka K, Pantazıs V (2012). Equality of the genders in Physical Education: The Studends' Perceptions. J. Phys. Educ. Sport. 12(3):350-357. 